\title{
Opportunities and Challenges of Online Banking in Nepal
}

\author{
Sanita Mastran, M.Phil. \\ Faculty, Sainik Awasiya Mahavidyalaya \\ ORCID: https://orcid.org/0000-0001-5831-5433 \\ Email: shrsanita@gmail.com
}

\begin{abstract}
This descriptive study aims at exploring the challenges and opportunities of e-banking in the Nepalese banking sector. The required data are collected from bank employees by applying a self administered questionnaire, semi-structured interviews and the desktop research. The findings demonstrate that banks expand to e-banking services in order to remain competitive, to update themselves with new technological developments and to minimize transaction cost and to facilitate customers. The major challenges faced the ebanking customers are non-familiarity with advanced technology, internet connection problems, problems regarding security and privacy. These challenges have a negative influence on the adoption of e-banking services by customers in Nepal. To overcome the challenges, Nepalese banking industry should invest on adopting the most secured and trustworthy e-banking system and educating customers on the use and importance of ebanking regularly.
\end{abstract}

Keywords: E-banking, opportunities and challenges, information technology, services

\section{Introduction}

Financial sector plays an important role in the economic growth of a country. Information and technology has become a very necessary tool in the current situation. Nepalese banking sector is operating in a globalized, privatized, liberalized and competitive environment. Strong and healthy banking system plays an important role in the economic development of a country. With the advancement in information and communication technology, the banking sector is subjected to this technological change and is adopting new technology based service options to remain competitive. One of the latest technologies adopted in the banking industry is internet banking. Using Internet banking, customers can perform financial transactions electronically through a personal computer, laptop, and mobile phones at a convenient time and from convenient places without reaching concerned branches in regular operating hours.

Internet banking is a very recent phenomenon in Nepal. The era of modern banking in Nepal started with Nabil Bank introducing credit cards in the early 1990s. Himalayan Bank had introduced an ATM and Nepali credit card for the domestic market in 1995. In 
2002, Kumari Bank introduced E-Banking (Internet Banking) service for the first time in Nepal. In 2004, Laxmi Bank introduced SMS Banking (Mobile Banking) service for the first time in the country.

In the starting days, online banking services were mainly used to check account statements only. Customers were not much aware regarding the purposes of online banking and its uses. It took a long time for online banking technology to be adopted widely. The adoption of the Internet and smartphone made online banking easy. Customers can now use mobile devices and the Internet to do their banking operation without visiting bank branches.

Banking organisations have been delivering electronic services to consumers and businesses for years. Electronic funds transfer, including small payments and corporate cash management systems, as well as publicly accessible automated machines for currency withdrawal and retail account management, are global fixtures. However, the increased world-wide acceptance of the Internet as a delivery channel for banking products and services provides new business opportunities for banks as well as service benefits for their customers (Committee and Supervision, 2003). Internet Technologies have the great potential to influence customers and the banking sector can grab many opportunities through its adaptation. The best example of adapting new technology, which has already revolutionized banking services is development of Automatic Teller Machines (ATMs). Another milestone is the invention of mobile apps for providing banking services.

E-banking adopters use the basic banking facilities such as cash receive and withdraw, balance enquiry, regular and scheduled payment. Only a few percentages use other facilities such as inter-account fund transfer and online purchasing. This is basically because of the security and confidentiality concern of the customers regarding these facilities of E-banking. Risk management, infrastructure development and policy formulation are the three major challenges of E-banking in Nepal. Technological problems like connection break in service while withdrawing cash from ATMs, poor mobile service are creating obstacles in the development of E-banking in Nepal. An adequate level of infrastructure and human capacity building are required before banks adopt full-fledged E-banking. In Nepal, E-banking is at its infancy right now and the system is not perfectly secure. However, no e-banking frauds have been found yet. Lack of understanding of internet technology may be the reason. But, precaution must be taken (Banstola, 2007). The agreed fact about security concern is the most critical factor that influences negatively the prospective customers of e-banking. 
Internet technologies have a great potential for fundamentally changing the banks and the banking industry. The opportunities, which the e-banking services and technologies offer to the banking sector in order to fulfill existing customer needs and to attract new prospective customers, are the driving forces for banks in order to design, develop and operate their own e-banking systems (Angelakopoulos, \& Mihiotis, 2011).

Internet banking is fundamentally changing the banking industry worldwide. Most of the developed nations prefer this mode of banking. The rise of internet banking will redefine business relationships and the most successful banks will be those that can truly strengthen their relationship with customers. There are plenty of issues that need to be explored from various perspectives such as Comparison between banks to see what role the banks are playing individually to educate their customers. A research should be conducted from the banks point of view (Ingle \& Pardeshi, 2012).

New Information technology has taken important place in the future development of financial services, especially banking sector transitions are affected more than any other financial provider groups. Increased use of mobile services and use of the internet as a new distribution channel for banking transactions and international trading requires more attention towards e-banking security against fraudulent activities. The development and the increasing progress that is being experienced in Information and Communication Technology have brought about a lot of changes in almost all facets of life. In the Banking Industry, it has been in the form of online banking, which is now replacing the traditional banking practice. Online banking has a lot of benefits which add value to customers' satisfaction in terms of a better quality of service offerings and at the same time enable the banks to gain a more competitive advantage over other competitors. This paper discusses some challenges in an emerging economy (Chavan, 2013).

Electronic banking, new strategies have become necessary in order to attract and retain existing customers, changing business environments, globalization and the advancement of information and communication technology. Despite enormous pressures for change and investment in information technology in the banking field; if these investments do not work in accordance with the principles of investment, they will fail (Shah, 2016).

Decision makers should consider focusing on the trust, awareness, and confidence of users by enhancing security features, utilizing proper e-legislation, and the provision of digital receipts or a guarantee for every transaction in order to inspire greater confidence in users of such services and promote a culture of e-banking usage across Nepal (Shah, 2016). 
There are quite a number of online payment services that have been developed within the payment system around the globe. These include electronic cheques, e-cash, credit cards and electronic fund transfers. Several types of online payment systems have been studied by who classified them into electronic currency and account-based systems. In accountbased systems, users are allowed to pay using their own bank accounts while the latter allows consumers to pay only with the help of some electronic currency. Both the systems provide numerous payment methods such as i) Electronic payment cards (credit/debit and charge cards), ii) Mobile payments, iii) E-wallets, iv) Smart and loyalty cards, v) Virtual credit cards, vi) Stored value card payment, and vii) E-cash (Khan et al., 2017).

The role of digitalization in the banking sector has altered customer's preferences and altered customer's preferences and demands (Dalvi 2018). Online banking is one of the most significant developments for the banking industry in its long history. However, despite the many benefits that online banking provides to customers, there are also a number of major concerns and challenges for marketers in the online banking sector. Traditional banking habits, security, technical issues, transaction difficulties, and small marketing budgets are all major challenges that online banking marketers will have to reconcile if they are to succeed in this field. However, demand for this industry continues to be very strong. So it is likely that online banks will only grow more advanced and successful as they strive to resolve their marketing challenges. However, despite the benefits of online banking, there are also a number of distinct issues and challenges in the online banking sector. These are highly significant both for banks that offer online banking, but also for their customers, who depend on the banks to operate effectively. Online banking marketers need to know these challenges so that they can efficiently navigate them (Palanisamy, 2019).

The main objective behind integrating banking services with technology is, undoubtedly, convenience. Technology has now become familiar to most individuals, to an extent that it influences their lifestyle. It, then, becomes vital for businesses to distinguish themselves in the digital space with unique offerings. Security remains part of the core services that banks can offer, and for this reason, the interfaces with simplicity work best. More customers are acclimatizing to mobile platforms, and more users are using online platforms at a much younger age. Due to these reasons, there is an undoubted power that can be leveraged through digital channels. In order to tap into the power of digitization, however, there are a number of challenges that need to be overcome (Palanisamy, 2019). 
This paper aims to explore the challenges and opportunities of e-banking for the Nepalese banking sector, and also presents the results of a survey of banking executives working at banks offering e-banking services. The main objectives of the study are to understand trends of use of internet banking services in Nepal, to identify the challenges faced by banks and customers using internet banking, to explore the opportunities for banks concerning the development of internet banking services and opportunities for customers, and to find out the challenges to be overcome by bankers and risk associated with the internet banking among the bank customers.

Table 1

Financial Access as on Mid-December, 2020

\begin{tabular}{llll}
\hline Particulars & $\begin{array}{l}\text { Class “A” } \\
\text { Bank }\end{array}$ & $\begin{array}{l}\text { Class ”B” } \\
\text { Bank }\end{array}$ & $\begin{array}{l}\text { Class “C” } \\
\text { BFIs }\end{array}$ \\
\hline No. of Financial Institutions & 27 & 19 & 21 \\
No. of Branches & 4,585 & 1,032 & 253 \\
No. of Deposit Accounts & $28,809,988$ & $4,052,622$ & 669,177 \\
No. of Loan Accounts & $1,210,923$ & 301,457 & 44,896 \\
No. of Branchless banking Centres & 1,619 & - & - \\
No. of Branchless banking Customers & 189,906 & - & - \\
No. of Mobile Banking Customers & $10,665,071$ & $1,151,807$ & 95,935 \\
No. of Internet Banking Customers & $1,029,333$ & 25,574 & 6,433 \\
\hline
\end{tabular}

Source: Nepal Rastra Bank

Following Information Technology based delivery channels are provided by banks in Nepal:

1. E-Banking (Internet Banking)

2. Mobile Banking

3. Plastic Cards

4. Automated Teller Machine (ATM) and Point of Sale (PoS) Machine

5. Mobile Wallet (Digital Wallet) 


\section{Methodology}

This study is descriptive in nature and data was collected from bank employees as the study aims at collecting and analyzing data regarding the current status and the possible ways of further e-banking service expansion and risks associated with the use of ebanking services for banks and customers in Nepal. Preliminarily, informal discussions were done with employees of different banks regarding internet banking, different facilities provided by the banks, problems in providing e-banking services, grievances related to e-banking and regarding service costs and charges.

Self administered questionnaire was designed and distributed to only " $A$ " class commercial bank employees. Data collection tool consisted of both semi-structured interviews of bank employees and self administered questionnaires. Desktop research was also performed by visiting the websites and mobile apps of different banks and websites of the Central bank of Nepal.

In this study, the semi structured interviews were conducted with a list of queries which varied from interview to interview according to experience of respondents. Face to face interviews were conducted and also cellphone was used due to time and location limitations. The information collected from interviews were used for qualitative analysis. Such interviews helped to identify the questions to be included in the questionnaire. By comparison, semi-structured and in-depth (unstructured) interviews are nonstandardized. These are often referred to as qualitative research interviews. In semistructured interviews the researcher will have a list of themes and questions to be covered, although these may vary from interview to interview. This means that one may omit some questions in particular interviews, given a specific organizational context that is encountered in relation to the research topic. The order of questions may also be varied depending on the flow of the conversation. On the other hand, additional questions may be required to explore your research question and objectives given the nature of events within particular organizations (Saunders, Lewis, \& Thornhill 2016).

\section{Growth in Electronic Payment Transaction}

The use of the electronic means of payment is increasing due to development of payment system infrastructure and policy of encouraging electronic means of payment. Electronic payment transactions have been increased due to easy access and minimum service charges. 
Table 2

Electronic Payment Transactions

\begin{tabular}{|c|c|c|c|c|c|c|}
\hline \multirow[t]{2}{*}{ Particulars } & \multicolumn{3}{|c|}{ No. of Transaction } & \multicolumn{3}{|c|}{ Total Amount (NPR in million) } \\
\hline & $\begin{array}{l}\text { Mid-July } \\
2020\end{array}$ & $\begin{array}{l}\text { Mid-Aug } \\
2020\end{array}$ & $\begin{array}{l}\text { Mid- } \\
\text { Sept } \\
2020\end{array}$ & $\begin{array}{l}\text { Mid- } \\
\text { July } \\
2020\end{array}$ & $\begin{array}{l}\text { Mid- } \\
\text { Aug } \\
2020\end{array}$ & $\begin{array}{l}\text { Mid- } \\
\text { Sept } \\
2020\end{array}$ \\
\hline $\begin{array}{l}\text { RTGS (Real Time } \\
\text { Gross Settlement) }\end{array}$ & 37297 & 34616 & 28137 & 1567959 & 1213870 & 835526 \\
\hline $\begin{array}{l}\text { ATM-Cash } \\
\text { Withdrawal }\end{array}$ & 6302846 & 4769340 & 3797969 & 54763 & 38393 & 32320 \\
\hline $\begin{array}{l}\text { Electronic Cheque } \\
\text { Clearing (ECC) }\end{array}$ & 1260169 & 1039330 & 677845 & 792007 & 657113 & 402477 \\
\hline IPS & 596538 & 347854 & 656142 & 223651 & 156360 & 153073 \\
\hline Connect IPS & 696447 & 633134 & 895586 & 51306 & 47367 & 61958 \\
\hline Debit Cards & 3316554 & 5426368 & 4118182 & 25894 & 41787 & 33667 \\
\hline Credit Cards & 119610 & 154698 & 76317 & - & 708 & 407 \\
\hline Prepaid Cards & 5249 & 8986 & 4587 & - & 57 & 30 \\
\hline Internet Banking & 653459 & 205735 & 208934 & - & 3082 & 4741 \\
\hline Mobile Banking & 5817681 & 5923411 & 5961339 & - & 18393 & 20340 \\
\hline $\begin{array}{l}\text { Branchless } \\
\text { Banking }\end{array}$ & 83249 & 53350 & 37344 & - & 1042 & 815 \\
\hline Wallet & 10179557 & 10177889 & 9415447 & - & 7579 & 7339 \\
\hline $\begin{array}{l}\text { QR-Based } \\
\text { payments }\end{array}$ & - & 195016 & 179150 & - & 589 & 648 \\
\hline Point of Sales & - & 532911 & 314110 & - & 1858 & 1223 \\
\hline E-commerce & - & 168627 & 87007 & - & 1201 & 561 \\
\hline
\end{tabular}

Source:(Nepal Rastra Bank[NRB] 2020)

\section{Status of Cards}

Though majority of payment is still made through cash and cheques in Nepalese economy, digital payment instruments i.e. ATM, Wallet, POS machine, QR code etc. are also gradually increasing. Following table provides the data on the number of prepaid, debit and credit cards and the number of Automated Teller Machines (ATMs). 
Table 2

Cards and ATMs Deployed

\begin{tabular}{llll}
\hline Cards & Class “A” & Class "B” & $\begin{array}{l}\text { Class “C” } \\
\text { BFIs }\end{array}$ \\
& Bank & Bank & - \\
\hline Prepaid Cards & 58,048 & - & - \\
Credit Cards & 168,682 & - & 38,369 \\
Debit Cards & $7,379,610$ & 251,848 & 51 \\
Total number of ATMs & 3,831 & 309 & \\
\hline
\end{tabular}

Source:NRB Monthly Statistics

\section{Mobile Banking and Internet Banking}

Mobile banking and Internet banking services are being provided by the Bank and financial Institutions to its customers which allows its users to perform financial transactions on digital mode like Electronic Fund Transfer, QR Payments, Utility Payments, Direct Debit and Direct Credit. Mobile banking is done by using a mobile device such as a Smartphone or tablet and Internet banking is done through the website. Following table shows the number of customers using mobile banking and internet banking in Nepal.

Table 3

Number of Customer using Mobile Banking and Internet Banking

\begin{tabular}{llllll}
\hline Channel & \multicolumn{5}{c}{ Fiscal Year } \\
\cline { 2 - 6 } & \multicolumn{1}{c}{$2072 / 73$} & $2073 / 74$ & \multicolumn{1}{c}{$2074 / 75$} & $2075 / 76$ & \multicolumn{1}{c}{$2076 / 77$} \\
\hline Mobile Banking & $1,754,566$ & $2,669,732$ & $5,086,069$ & 8347187 & 11306797 \\
Internet banking & 515465 & 783751 & 834302 & 917344 & 1031227 \\
Change in Mobile Banking & $52.16 \%$ & $90.51 \%$ & $64.12 \%$ & $35.46 \%$ \\
Change in Internet Banking & $52.05 \%$ & $6.45 \%$ & $9.95 \%$ & $12.41 \%$ \\
\hline
\end{tabular}

Source: Nepal Rastra Bank

In FY 2076/77, the number of mobile banking users increased by 35.46 percent and reached 11,306,797. Similarly, the number of internet banking users increased by 12.41 percent and reached 1,031,227. The major reasons behind using e-banking service are time saving, flexible hours, accessible from remote areas.

\section{QR Code based payment}

Recently QR Code based payment service has been started by one of the PSO (FonePay Payment Service Ltd) and some of PSPs (IME Digital Solution Ltd, Q Pay Pvt Ltd, 
Sparrow Pay Pvt Ltd, Cellcom Pvt Ltd and Nepal Pay Time Pvt Ltd). QR Code based payment system is one of the cheapest and easy payment platforms for instant payment. Customers can pay a merchant after scanning the QR code plate through mobile. NRB is encouraging QR code-based payment and accordingly developing QR Code Standard and Guidelines.

\section{Instant Payment}

Instant payment includes connect IPS and QR Code based payment. Connect IPS is one of the most popular products, at public level, offered and operated by NCHL since Shrawan 2075, where the system allows the bank customers to make instant payments. In Fiscal Year 2076/77, total number of connect IPS transactions increased significantly by 1431.90 percent and reached 2,849,964.

Table 4

Total number of transaction through Instant Payment

\begin{tabular}{lcc}
\hline Particulars & \multicolumn{2}{c}{ Fiscal Year } \\
\cline { 2 - 3 } & $2075 / 76$ & $2076 / 77$ \\
\hline Total Transaction & 186,041 & $2,849,964$ \\
Growth in Connect & & $1431.90 \%$ \\
IPS Transaction & & \\
\hline
\end{tabular}

Source: NCHL

\section{Opportunities and Challenges of Online Banking}

Information collected during the interviews were used for qualitative analysis. Semi structured interviews covered a list of themes and questions. Interviews conducted with managers and senior officers of different commercial banks of Nepal portray the point of view and the opinions towards on-line banking. All the listed views are described below. Both bankers and customers have as well as challenges from internet banking services in Nepal. According to different interviews conducted with the employees of different banks and different branches, opportunities and challenges identified are as follows.

\section{Opportunities for Bankers}

\section{i. Banks can access new customers}

Internet technology has the potential to fundamentally change banks and the banking industry. All banks can benefit from e-banking by offering innovative products and accessing new customers.

ii. Banks can provide services to customers of remote area 
Banks can offer their services in areas where they have no physical presence in the form of branch and extension counters. They can benefit from the reduced costs of e-banking instead of establishing a new branch in a remote area. They can access new geographical areas without establishing new branches.

\section{iii. Bank can minimize their operational cost and maximize income}

Banking transactions through multiple channels of e-banking can reduce cost than establishing new branches and investing on staff and other regular operating costs. The cost of a banking transaction in a physical branch cost higher than transaction cost performed through e-banking.

\section{iv. Workload for Bank employees can be reduced}

Tellers and bank officers' work load can be reduced and they can spend working time more efficiently as the number of customers on the queue becomes less and banks seem less crowded. Bank employees and customers often feel stressed and less comfortable looking at the length of queues.

\section{v. Service quality provided to customers can be upgraded}

Bank offering e-banking services is perceived as an innovator and technologically leading in the banking industry. Their public image is perceived far better than other banks. The good name and reputation of a bank helps to strengthen the brand and image in customers' minds. Good perception towards the bank and less number of customers inside the bank can improve service quality.

\section{vi. New opportunities can be created}

The internet has created many business models (E-commerce, e-money, e-payments, eshopping, e-sewa, digital wallet, QR code etc) which creates many new opportunities having lots of potential to attract customers and retain existing customers.

\section{Challenges for Bankers}

\section{i. Security risks}

Every channel of online banking has its own security problems, but for bankers due to security risks customers may switch to other banks. Internet connection problem, hackers, computer viruses, spyware, malware and many other issues are concerned in ebanking. There are many cases of theft, fake ATM cards, password hacking etc which creates challenges for bankers. This is the most critical factor that negatively influences customers of e-baking. 


\section{ii. High investment in Adoption of new technology and maintaining the technological infrastructure}

High investment is required in the initial stage to install new technology for e-banking. To design, develop and implement e-banking services and supporting new technology huge budgets are required. Besides the initial investment maintenance costs for servers, database management, security systems, software upgrading, networking, telecommunication technology maintenance demands huge amounts of budget of a bank.

\section{iii. Training for staffs}

The staff are responsible for operating alternative channels of online banking. Staffs must have good knowledge about new technologies, business and legal matters to operate an online banking system. There should be different training programs for the bank employees in order to acquire the skills and background required for promoting the use of e-banking to customers of their bank.

\section{Opportunities for Customers}

\section{i.Time saving}

Customers are free to use the service and perform transactions 24 hours per day all the year from a convenient place. This alternative channels for using banking service are not limited to office hours which saves time of customers.

\section{ii. Access from remote areas}

Customers can gain access to their bank accounts from remote areas also where they could connect to the internet. They can pay tax, utility bills, administrative expenses, loan installment, insurance premium and perform other banking transactions from any part of the world, the only requirement is internet connection.

\section{iii. Very low charges and often cash back offers}

Banks charge less than NPR 500 or even free services are provided for e-banking. Customers can perform many transactions as per their need without any cost. The exceptional case is only incase of using an ATM through other banks. Banks are also providing cash back offers and discounts for motivating customers to use online payment systems and performing e-banking transactions.

$i v$. Easiness in paying utility bills 
Customers can easily pay telephone bills, drinking water bills, electricity bills, tax and many more where most customers have to get in line for several hours to pay bills. The customer can spend time more efficiently rather than standing in those queues.

\section{Challenges for Customers}

\section{i. Infrastructural Barriers}

Though customers have mobile and laptop devices with internet connection, there are many infrastructural barriers including telecommunication networks, bandwidth capacity, electricity, special equipment and devices and many more. Sometimes customers get in trouble due to these barriers. It is one of the challenges for implementation and development of e-banking in Nepal.

\section{ii. Lack of technological skill}

Technological skill is most essential to customers to operate e-banking transactions. Non-familiarity and lack of required technological skills (using computers, ATMs, Mobile phones) cannot benefit from e-banking services. Most customers have problems browsing the internet.

\section{iii. Security issues}

Security issues are the greatest challenge for adopting the e- banking products and services by the customers. Personal information may be misused and bank accounts may be hacked. Security issues have been identified as the most important challenge for customers as well as bankers.

\section{Discussion}

Though there is rapid growth in Nepalese financial sector, E-banking is still in its infancy. E-banking has a huge prospective to contribute to the financial system of Nepal. Certain segments of the consumer group are only using Electronic Banking. Consumers are less aware of risk involved in E-banking. Banks are investing lots of money in technology but they have not been successful enough in E-banking activities. If the banks do not see the scenario and challenges of E-banking, they cannot be profitable. In this context, this study aims to find answers to the following questions. 1. What types of E-banking services customers want? 2. Can E-banking service be profitable? 3. What are the risks involved in E-banking? 4. Are the banks using sufficient risk management tools to assure secure financial transactions? 5. To what extent electrical and telecommunication infrastructure is available in Nepal? 6. What personal characteristics and demographics do e-banking adopters have? 
Shah (2016) suggested that decisions makers should consider focusing in the trust, awareness, and confidence of users by enhancing security features, utilizing proper elegislation, and the provision of digital receipts or a guarantee for every transaction in order to inspire greater confidence in users of such services and promote a culture of ebanking usage across Nepal. Nepalese customers lack knowledge of the internet and Ebanking, so customers should be well informed about the procedures of using the service. They should be trained by experts organizing different training and workshops. Only friendly mobile apps and websites cannot gain customers trust.

Singh (2012) recommended that banks should concentrate more on educating their customers about internet banking and the level of security. Customers who don't use internet banking have a very negative perception about the security issues. The study also identified the need for the banks to promote online banking services and proper promotional activities are not taking place. Seminars should be conducted to educate people about the benefits of internet banking and to clear their negative perception about it. The author also suggested that Print media and newspapers can be used to educate people about internet banking.

The e- commerce consumer behavior model stimulates a consumer to think about buying. Buying decision making is affected by either individual factors or environmental factors. But in electronic commerce, additional factors also influence buyer's decision making, payments, delivery, web designs, use of intelligent agents and customer service. Although there has been competition amongst Banks and Financial Institutions (BFIs) to deliver modern banking services, the majority population in the country has no access to such services. The reason for this is the concentration of BFIs in urban areas. Modern banking services are available in urban areas only, with most people in rural areas being deprived of even the basic banking services.

Banking fees, low literacy levels, and inaccessibility of bank services in rural areas due to poor infrastructure are considered for the low adoption of digital banking services.

Likewise, underdeveloped digital financial services ecosystem with low credit and debit card penetration, low use of digital payments, online and mobile banking, and restrictive government policies (e.g., low maximum limit of digital payments) are thought to be hindering the expected growth and adoption of digital banking and payments services in Nepal.

Ingle and Pardeshi recommended that banks should concentrate more on educating their customers about internet banking and the level of security. Customers who don't use internet banking have a very negative perception about the security issues. There is a 
need felt for the banks to promote online banking services and proper promotional activities are not taking place. Seminars should be conducted to educate people about the benefits of internet banking and to clear their negative perception about it (Ingle \& Pardeshi, 2012).

\section{Conclusion}

This study shows that most of the commercial banks have online banking facilities in Nepal but only limited services such as Account information, fund transfer, balance inquiry, statement view and print, fixed deposit account opening, utility payment, credit card management, connect IPS/IPS, Fonepay, Wallet. E-sewa and QR code etc are provided by the Banks through the online banking system. The study also explored the challenges faced by the banks for the development and changeability of services offered. Customers' knowledge about the internet, technical know how, Language problem, concerns about security, trusts, infrastructure, management issues regarding customer care, etc are major challenges faced by the banks for the development and adjustability of internet banking. The study also shows Customers are unaware of the security policies, service charges, risks associated with internet banking services. Internet banking is shadowed by mobile banking. Banks are focusing on customers who might go abroad for studies or work because it is really useful for them to get informed about their bank account. Internet banking registration is free of cost in most banks but due to lack of internet knowledge of our customers, the number of enrolled customers is very low in Nepalese banks. Banks are reaching out to younger generations who are techno friendly and most probable users of internet banking. The study reveals main reasons behind customers visiting banks are for making deposits, cash withdraw, loan payment, request for debit cards or cards and balance inquiry. The study also explored that most customers have to visit banks for registering to use online banking. Also, customers have to pay minimum charges (less than NPR 500) annually for using online banking services. Banks also provide Banks are focusing on user friendly system. Awareness program, financial literacy program, campaigns have been practiced by bankers to attract customers in online banking.

The main findings show that banks expand to e-banking services in order to remain competitive, to adapt technological developments and to make profit by minimum cost of e-banking transactions. The major problems they face are the low response rate from customers and the implementation of security and data protection mechanisms. The relatively low Internet usage, the non-familiarity with technologically advanced devices and problems regarding security and privacy are the main factors that have a negative influence on the adoption of e-banking services by customers in Nepal. To grab the 
opportunities and tackle the challenges provided by the e-banking system, the banking institutions must invest more on convincing the customers that the banks have adopted more advanced system to make transactions secured and trustworthy. By the mean time, e-banking education program to the banking customers is also required to uplift the industry in this regard.

\section{References}

Angelakopoulos, G., \& Mihiotis, A. (2011). E-banking: Challenges and opportunities in the Greek banking sector. Electronic Commerce Research, 11 (3), 297-319.

Banstola, A. (2007). Prospects and Challenges of E-banking in Nepal. The Journal of Nepalese Business Studies, IV (1), 96-104.

Basel Committee on Banking Supervision (2003). Risk Management Principles for Electronic Banking. Electronic Banking Group of the Basel Committee on Banking Supervision. Washington DC.

Chavan, J. (2013). Internet Banking- Benefits and Challenges in an Emerging Economy. International Journal of Research in Business Management, 1 (1), 19-26.

Dalvi, S. V. (2018). Digitisation in Banking. International Journal of Trend in Scientific Research and Development (Conference Issue), 197-203.

Ingle, A., \& Pardeshi, R. (2012). Internet Banking in India: Challenges and Opportunities, IBMRD's Journal of Management \& Research, 1 (1), 13-18.

Khan, B. U. I. et al. (2017). A Compendious Study of Online Payment Systems: Past Developments, Present Impact, and Future Considerations, International Journal of Advanced Computer Science and Applications, 8 (5), 256-271.

Nepal Rastra Bank. (2020). Current macroeconomic and financial situation of Nepal. Nepal Rastra Bank. Kathmandu.

Nepal Rastra Bank. (2020). Banking \& Financial Statistics Nepal Rastra Bank,” Banking \& Financial Statistics, Mid-Dec, 1-61. Nepal Rastra Bank. Kathmandu.

Nepal Rastra Bank. (2020). Payment Systems Oversight Report. Nepal Rastra Bank, Payments Systems Department. Kathmandu.

Palanisamy, R. (2019). Digital Banking Challenges and Opportunities in India. EPRA International Journal of Economic and Business Review, 7 (2), 20-23.

Saunders, M., Lewis, P., \& Thornhill, A. (2016). Research Methods for Business Students. United Kingdom: Pearson Education Limited.

Shah, K. K. (2016). Electronic Banking: Its Use and Challenge in Nepal. Academic Voices: A Multidisciplinary Journal,5 (1), 9-15. 